\title{
Contribution of Austrian-Hungarian Empire in the development of Education in Shkodra till notification of the Independence of Albania
}

\author{
Kujtim Pelinku \\ University of Shkodra"Luigj Gurakuqi", Department of Education \\ Email: kujtimpelingu@yahoo.com \\ Dr. Eranda Bilali (Halluni) \\ University of Shkodra"Luigj Gurakuqi", Department of Education \\ Email: erandabilali@yahoo.com
}

Doi:10.5901/mjss.2014.v5n3p368

\begin{abstract}
The relations of Shkodra region in the education's field with Austrian-Hungarian Empire have had an early traditon. The attempt to identify this employment link brings some new fact in the context of this cooperation, over a period of time from 1850 to 1912, Albanian Declaration of Independence. Based on the time's statics, various writings, archival materials and documents to Vienna's archive, we are trying to identify the values of this contribution in education, in functioning and spreading of schools and allowing the Albanian language in schools that held the function on the basis of this contribution. It is important to be noted that these schools played an important role not only in the education of the new generation, but soon Shkodra turns into an important educational centre.
\end{abstract}

Key words: Austrian-Hungarian Empire, contribution, operation, Albanian language, clerical schools.

\section{Introduction}

In the frame early relationship between Albanian and Austria, Shkodra caught the eyes, as a permanent cradle of knowledge, an island of patriotism, a city shown up for its cultures and traditions. Even though, the relations between them have had a long and early tradition, many documents, oral information, official statistics (Turkish, Austrian, and / or Italian), different articles published so far certify the Austrian-Hungarian contribution, especially in development of education.

The school and cultural life in Shkodra has been standing up for several specifics as per the number of schools and their nature. The educational activity for first decades of century XIX had a low development level, because limited social - economic relations decelerated development at schools. Under the complex social - pedagogical conditions, there were attempts to open / establish schools and education in Albanian language. Those attempts were results of Albanian intellectuals, private initiatives, and influence of cleric, under support of Austrian - Hungarian Empire.

The Austrian influence in Albania, besides others, is linked with protection of rights by the Christian Church during the Ottoman's Empire assuring several international treaties. Starting from year 1615, year in which the peace between Emperors, Matie and Sultan Ahmet II, have been signed, that during years 1682, 1718, 1768, and 1791 took the name of called politics of cultusporat, the Austrian - Hungarian Empire had the right of auditing of these treaties and in 1837, the Pope passed to Austrian protection of rights for Catholisim in Albania (Fishta, 1917).

Under the frame of cultusporate, Vienna implemented broad cultural, educational, scientific, religious, and propagandistic activities. The defined precaution by them got the name "Action Programme" with two major goals: schools and churches, by anticipating usage of Albanian language at schools and equipping them with Albanian books. So gradually cultursprotectoriate expanded not only from catholic population but also to whole nation including non Catholics inside territory.

In Albania, the Austrian educational policy and its increased effects in cultural and educational development in some nations is linked to and has assisted even with some legal provisions of Vienna's government. In year 1848, it 
drafted the law, according to it,..."at elementary schools, kids should learn their mother tongue language and it became mandatory that lessons to be held in mother tongue language for those children who attended the schools". Such a thing has been reinforced with legal provisions of year 1849, when article 17 of the Austrian state's law dated 21 December 1967 on problems of education, stressed that "each nationa has the right to save and cultivate its individuality and language at schools", and that "in those regions where several nationalities live together, the schools should be regulated in a way in order to cultivate even the language of another nation " (Zhlebnik, 1964). Since that period, the Austrian - Hungary empire tried by serious attempts to establish schools in Albanian language. The Turkish government could not shut them down, which were motivated due to religious motives. It has been published in "Leka" magazine that: "who would have the courage to say any things on establishing of schools in Albanian language? It is necessary the power, one Austria, that will impose Turkey to allow opening of schools in Albanian language only for Catholics with justification as per religious schools ${ }^{1}$. This was the reason why at schools of catholic children was freely learned Albanian language.

Due to this policy and goals of Austrian -Hungarian Empire, the reconstruction and maintenance of churches was under the attention, preparation of catholic pulpit in establishing of schools for Albanian initially in Italian and then, in year 1902 in Albanian language, the leadership of which was trusted on catholic pulpit.

Up to notification of Independence, the Austrian - Hungarian Empire subsidized in Vilajet (Region) of Shkodra 47 elementary schools, where 10 out of them were for females (Asllani, 2000).

Regarding schools in Vilajet of Shkodra, there were many schools which have existed in both cities and other parts of this region. At other schools in the city of Shkodra, Turkish language or other foreign language was taught, such as Italian or Serbian, but not in Albanian language. Schools in Albanian language were subsidized by Austria.

As an organization way of work at schools were mejtep-s (Ottoman type of schools) and later on medrese-s. In Shkodra, mejteps existed near each cult institution. Although they were not in Albanian language, their attendees took reading and writing skills as well as culture, under conditions that lacked schools in mother tongue language. "Besides mejteps, since year 1830 the private catholic schools started functioning, which under the pressure of "Capitulations", Turks were obliged to allow them, so the Catholic element of Shkodra had a greater possibility of education and to have more contacts with Albanian written language" (Luli, Dizdari \& Bushati, 1997)

Exactly in Shkodra since year 1800 till 1861, there were 12 elementary schools, 8 for boys and 4 for girls. "Premises were small and primitive, so it is not to be seen as progress... worth, to bet from there, the initiative, the heroic step, will to spread culture. One teacher represents a school in a country. The parents hardly waited to send their kids to school, even they promised to pay the teachers" (Kurti, 1935). "Geg Kodheli... was the first teacher here in Shkodra, who put to teach children. He was graduated in Venice (Venedic)"2. Then Gjergj Benusi on 1836 open and furnished the school, but, meantime, he taught in Italian, the teacher Gjo Shkrumi taught children to read and write in Albanian. We mention teachers: Jak Speci, from Shkodra, his school was attended by 30 children. Jaku except Albanian language, he taught children the second language because the Austrian Consulate in Shkodra paid 15 napoleons (golden coins) per year (Qafëzezi, 1936). Zef Kamsi from Shkodra etc, who got 10 stiver per month ${ }^{3}$ (1915). These "educational centers", established in different neighborhoods in the city, developed a limited activity due to prosecution of Ottoman authorities occupants (Prendushi, 1974) and due to bad conditions of premises and their low level. They did the lectures under hidden conditions, had narrow educational programmes and were attended by a limited number of pupils. Despite the fact that the importance of those educational centers was huge, because they expressed the will and attempts of people and patriots for education and culture, as well as those centers became first spots for spread writing and reading especially in mother tongue.

These "educational centers" have privately remained open till year 1855, year in which Shkodra'straders and Prelate, by looking at fact that teachers did not fulfill demand of times, with mediation of consul they invited from abroad foreign teachers who started working during academic years 1855-1856. In 1855, Arch Bishop had an elementary school with civilian teachers in the city. The teachers were selected by Arch Bishop himself and he paid them by 1200 golden coins, which were paid by Austria (Kurti, 1993). "Being student of school of Gjergj Benusi, there were added more, and it was necessary, in year 1856, more teachers from abroad were invited... Shkodra people sent and took those four teachers Mark Rebeskini, Gjuriqi, Luigj Katraninqi, and, together with Gjergj Benussi who were found in Shkodra, one school was open only with four classes.... Some Shkodra people provided 40 golden coins (napoleons) but this sum was insufficient, it was necessary that Austrian government that took the responsibility to pay the salaries of teachers. This

\footnotetext{
${ }^{1}$ Revista "Leka", nr. 10-12, Shkodër, viti 1938, fq. 444

2 "Përparimi", Shkodër, 1915, nr.6, fq.113

3 “Përparimi", 1915, nr.10, fq.184
} 
school did not last very long, because the first three teachers got bored and returned to their county, so Gjergj Benussi was again alone, who had learned Albanian and was because half Shkodra's person, because his name was tighted with fate of citizens"(Dituria, 1928).

By looking at situation of those early schools, Emzot Topiç (Bishop of Shkodra, our note) and his will to bring Francescans to Shkodra, in 1857 he sent a letter to General Head of Francescans in Roma that besides others he would write "... Regarding tools besides efforts, besides that support where francescans had by catholic inhabitants, they would have taken under their responsibility to teach children. Because of this, they have released an annual aid at about 1200 golden coins (napoleons) by Royal Apostolic Majesty" (Dituria, 1927).

But where the lesson will be held?

In 1855, the Francescans used 2 rooms of a building that People of Shkodra had donated to Francescans, in a quarter of Gjuhadol (name of a quarter) , a building that they have used as a shelten when they came back from mountains. So the school was established and led by Francescans. The progress was huge. In reports sent by the Austrian Consulate to its Ministry, on $4^{\text {th }}$ July 1863 , informed exactly about schools that people called "Paternal Schools". It was written in it that:" ...Since 1855 there is an elementary school in Shkodra. This was led before by civilian teachers, but it was seen as necessary the need of teachers by Francescans missionaries. The programme in this school is split into four classes and they study these subjects: Religion, Calligraphy, and first elements of Italian grammar. This institution has been supported by our government by 1260 golden coins from Austrian government, as well as by the Association Religious Charity "Holly Lady" - "from those donations the expenses to pay the building and teachers. Two months ago, the man in charge was tough with exams of pupils and how he provided awards to pupils of this school who was split by Emzot Çuçija, epyscolog of Shkodra" (Archive Francescan of Shkoder). In 1867, due to good progress of this school Emzot Pooten (Head of EpiBishop, instead of Emzot Çurçisë, our note), it was seen as necessary to increase the number of teachers, so I ask you to augment the aid from 1260 golden coins to make it 1560 golden coins per year in order to assure the salaries for one more teacher, because the pupils are increasing each day. This request was admitted, especially, because it was supported by the Austrian Consulate in Shkodra. It should be stressed that"... out of above sums 600 golden coins was kept by religious people, and the rest for Gjergj Benussi and two Shkodra's ladies who worked with handicrafts at a school with girls of the city" (Dituria, 1927)

The more time passed by the more increased the number of pupils. Due to it, the need for additional school raised. Again the Austrian government replied positively for support. It provided 3000 golden coins (Archive Ipeshkvor Shkoder) in year 1876. Due of first aid assured, without forgetting contribution of Shkodra people, the school constructed by francescans in year 1877 was transferred to a new building. The school marked progress regarding implementation of lessons, how pupils respected its rules, and the incensement of pupils. As a result of these achievements, again, there were demands for enlargement of premises. All was completed within a short time, even a salon that was used as a theatre where pupils will present different shows. In 1899, the simple programs were designed, new subjects, new tools and equipment, increased number of class-rooms, and the salon was enlarged in yard of school in 1901 in which a shelter was constructed in order to host children for leisure during rainy days. This school functioned till 1902 when At Gjergj Fishta became its head. Since arrival of Fishta, this school used Albanian language to do the subjects. Under his leadership, the school took another direction. The Italian language was lifted, except the elementary classes, the citizen classes were increased, accordingly the Austrian school programs. A special vitality was given by theater shows, in which population participated in order to increase the patriotic feelings. The number of pupils increased up to 300 . On 24 March 1912, this school was visited by the Minister of Internal Affairs of Turkey, who prized the good work of both teachers and pupils. The Prefect of city (Vali) and the Army's Commander often provided money to help poor pupils of this school (Zani I Shna Ndout, 1919).

In year 1886, there were 14 schools, but at the eve of First World War there were 28 schools. The chart bellow provided a full view of schools subsidized by the Austrian - Hungarian government till year 1912.

\begin{tabular}{|l|l|l|l|}
\hline Location of school & Nr. of schools & Nr. of teachers & Nr. of pupils \\
\hline Shkodra & 6 & $32(?)$ & 1210 \\
\hline Districts of Shkodra & 12 & 13 & 325 \\
\hline $\begin{array}{l}\text { In some other regions in } \\
\text { Albania }\end{array}$ & 7 & 10 & 200 \\
\hline Total & 25 & 55 & 1735 \\
\hline
\end{tabular}


As we can see from the chart in Shkodra, 6 schools functioned from which we are mentioning:

1. (Kolegjia e Shën Françesk Saverit) Collage of Saint Fracesc Saveri (1877) lead by Jezuits. This school was attened by 400 pupils and $10-12$ teachers taught there.

2. (Shkolla françeskane) Francescan School (1861), lead by francescns with 150 pupils where besides francescans there were 6 teachers.

3. (Instituti i Shulbruderve) - Institution of Shulbruders (1908), with three teachers and 120 pupils.

4. (Shkolla Femërore e Stigmatineve) -Stigmentins Feminile School (1878), with 3 teachers and 200 pupils.

5. (Azili i Motrave Servite) - Azilym of Servite Sisters (1898), with up to 300 pupils age 4 to 6 years old.

6. (Shkolla e Tinës së Nikës për vajza) - School of Nike's Tina for girls. Here two sisters Tina and Gjystja were teachers.

In District of Shkodra

1. Mirdita had 3 schools with three teachers

School of Oroshit, with 30 pupils and teacher Kolë Domen.

School of Kashnjet, with 20 pupils and teacher Kol Lacen.

School of Spaç, with 20 pupils and teacher Zef Ndoci.

2. In Puka: 1 school in Iballa (1903), with 15 pupils and one teacher.

3. Zadrima, 1 school in (1904), with 25 pupils and teacher Karlo Shiroka.

4. Bushat, 1 school elementary in (1900), with 50 pupils and teacher Gaspër Harusha.

5. Rranxa Bushat, 1 school in (1900), with 20 pupils and teacher Hil Agostinin.

6. In Dajç i Bregut të Bunës, 1 elementary school in (1903), with 30 pupils and teacher Shtjefën Maçi.

7. Daj̧ $i$ Zadrimës, 1 school in (1902), with 25 pupils and teacher Kol Zezën.

8. In Shiroka, 1 school in (1894), with 30 pupils and teacher Ndoc Ronkali.

9. Barbullush, 1 school in (1902), with 30 pupils and teacher Lush Kola.

10. Juban. 1 school in (1906), with 30 pupils and teacher Gjon Qerraxhia.

In some other areas of Albanian, there were open schools in Skopje, Prizern, Gjakova, Peja, Zym, and Durres, altogether 7 schools, 10 teachers, and 200 pupils.

\section{What was the concret contribution of Astrian- Hungarian Empire?}

In May of year 1856, the Austrian Consul Rudolfo Borovitzka started to contribute regularly to schools. In reports sent to Vienna nr 840/20 year 1857 for changes occurred during academic year in Catholic schools funded by the Austrian government was said that "In annual exams of end of year (on 31 May assited Borovitzka and Peshkopi Topiç), where awards were distributed, the resul was satisfactory. The number of pupils was 174, increased more than previous yea". (Archives of Museum of Shkodra, archives of Vienna).

Often the Archbishop sent intructions to teachers regarding educational progress. One intstruction that was prepared on 30 September 1856 said that:

"It should be 5 classes in schools days, 3 hours before lunch and 2 hours after lunch. In December, January, and February children should not go to home, but they should bring their luch with them. On Sundays and Thursdays, (only after lunch) will be held a break. If the feasts are on other weekdays then you should take advantage to use the thurday afternoons. Don't panish or bea (Archives of museum of Shkodra, file of education)

The exams were held in presence of the Austrian Consul and Bishop Mr.Topiç. The small ifts were delivered to pupils and some little money. The number of pupils from boths genders were 1858 and 177. (Archive of Museum of Shkodra, archives of Vienna). Regading staff, it was composed of three teachers, Austrian citizen Gjuriqin, Luigj Katraniqin, and the third teacher Marko Rebeschini. He was the last one to give up his duty on 21 Januar and he was substituded by the citizen Gjergj Benusi. During this period, the consul proposed to the Austrian government to reduce three mixed existing schools and creation of 2 schools for boys and one for girls. In this femaile school were brogut "Motrat e Mëshirës/Sisters of Merci" from Raguza.

"For a school of girls, expected a great benefit in terms of civilization from here."argues in the requisition sent to 
Vienna, which marks the date 23 september 1858 (Archive of Vienna)

Even in 1859 the exams in three Catholic elementary schools were conducted in presence of monsignor Çuçia, the Austrian consul and the schools provided satisfactory results where monsignor Çuçia delivered school equipment to best pupils, but the Austrian Conusl Borovitzka, the most hard working pupils, parents of whom were poor he provided gifts and money. The number of pupils were 132 out of them 61 belonged to lower classes and their teacher was Gjergj Benusi, 40 pupils of high school had their teacher Katoniqi and 31 pupils had their teacher Gjuriqi. "This number compared to last year was 45 times smaller that came due to absence of pupils who had adverse weather conditions such as hot weather of the summer in that year". (Archives of museum of Shkodra, archives of Vienna, 1859).

Later than 1959 the subsedizes by the Austrian government continued, even in letter date 17.09.1859 that comes from Vienna we learned that "...the committee of association on feast of Saint Maria, on 8 December, decided to provide a help of 600 Austrian golden coins for the Catholic elementary schools" (Archive of Vienna, 1859). In 1861, the first popular school was open by Francescans Priests. So it marked the end of private schools in quartiers with one teacher and a unique school was established for whole residents.

The Albanian Papnor Seminar was open on 2 August 1859 in Shkodra. Besides latin language in this school, the Albanian language was also taught too. The subjects in Albanian language have taught by honorable teachers such as At Justin Rrota, Dom Ndre Mjeda, At Anton Xanoni, and Jak Jungu. This last one has been mentioned for books "Gramatical elements of Albanian Language" (1881), "Small Vocabolary Albanian - Italian" (1895). Those albanian hardworking teachers, albanologs, authors of books, etc.. have educated to pupils the love about their mother longue language.

The requests to open one school for girls have been continuous, by making agruments that "...only mitigation and education of females that is getting tighted with old customs, obstruct any progress, it can place a foundation for civilization of Albania. By opening a school for girls a suitable and well organized we can put the baze for education of females who have been left behind" (Archive of Vienna). Çurçia promised to bring two sisters from an Austrian Institute. Each siter per school will be assigned. They will provide elementary knowledge and handy craft works necessary for females. Because at boys' schools were attending only little girls up from 5 to 10 year old, the females' schools will be attended by girls of any ages and they will get any high appropriate education.

Kushë Mica and Tereze Berdica in 1859They open the first private school for education of girls, the schools which was financially supported by the Austrian Government. Those teachers taught in Albanian language. In year 1865, this school had 86 girls. (Shkodra, 1965) One of best students of Kushë Mice, Tina Nik Gjergji opens an Albanian for girls in year 1873-74. The subjects that will be taught were: reading, writing, counting, drawing, music, and arts (handy craft works). The contribution of those schools was huge that we can say" ....the women in Shkodra even more than one hundred years ago (we are talking about century XIX, our note) could write in Albanian" (Koliqi, 1972)

As means for living, Kusha, Tina, and Tereza have had the revenues that assured by some families which were good financially, but they benefited, from their requests sent, an annual fund from Austrian foundation. "Since 1880 the quittances started to be paid back by the Albanian teachers for girls by Austrian government. Kusha and Tina, they have continued up to 1896-1897, but for Tereza till 1889 since opening of Italian school. Documents say that the aid has started since 1880, but Guerini in one of his reports says that they have been helped since at opening of their schools". (Archives of museum of Shkodra, file of education)

In September of year 1883, the Monsignor Pashko Guerrini, archbishop of Shkodra, sent to the Austrian Consul a request to help schools. "The aid is 1260 golden coins per year. The Francescan school gets 1.100, Kusha Micja and Tereze Berdica 75 (together) for each semester, Tina and Nika 10 golden coins (Archives of museum of Shkodra, file of education)

The private Albanian schools for girls were financed little, but teachers asked for that helpt to legalize their school and to have protection by another power out from Turkish pressure, otherwise they will not open those schools within the territory in their city under the eyes of Turkish authorities.

After continues request of Guerrini to help the private female schools, the Austrian - Hungarian consul Ippen sents to the Archbishop this letter (Archives of museum of Shkodra, file of education)

Shkodra, 17 October 1889,

Dear Excellency, Dear Emperor Monsignor

"I am honored to inform Your Exellency very much prised and High Emeprial Minister and Royal whom have excepted to 
donate even for next year subsides of 200 golden coins to the private school chaired by teacher Marie Mici. And because he is present, I plea your Excellency to inform the benefitor of that sum to withdraw it by a receipt." Excellency please except my high consideration and feelings and respect The Consul of Royal Empire. Ippen

In last quarter of last century XIX, Italy openly started to to competer the Austrain - Hungarians, by pretending for economic, political, and cultural expansion in Balkans. So in scope of education the italian interests were put versus those with austrians. The italian penetration was favoured by politics of Ottomane government. This last one permitted opening of Italian schools in Shkodra, in Durres, etc.. in 1889. The Catholics fighted those schools, due to the fact to remain loyal to dualist Empire of Habsgurgs, as same as the fact that their progrmms do not have religious subjects. The Italian school for boys and girls as well as Itailan azylium for pre - school children were open on 1 January 1889 (Archives of museum of Shkodra, file of education)

Table 1. The situation of schools in1889

\begin{tabular}{|l|l|}
\hline Sschools & Number of Pupils \\
\hline Francescane School & 250 \\
\hline Kolegja Saveriane & 100 \\
\hline Female School of Stigmatine Sisters & 284 \\
\hline Male Italian School & 125 \\
\hline Female Italian School & 70 \\
\hline Italian Azylium for pre school children & 220 \\
\hline
\end{tabular}

Source: Archives of museum of Shkodra, file of education

As it is shown by the chart Shkodra has 2 Italian schools, 1 male school, 1 female school besides the azylium with both genders. When the Italian schools were open there was a decrease of number of pupils registered and attendees of private schools at Tina Nika. For this she wrote: "The poor situation in country and gratis opening of schools by nuns (1879), shocked much my school and my life. For these reasons and after opening of Italian schools (1889), keeping of my school was something doubtful" (Archives of museum of Shkodra, file of education)

In the letter of Guerrini sent to the Austrian - Hungarian Consul in Shkodra on 18 March 1890 we learned that the aid of Austrian continued and asked that school of Kusha Mici was attended by 40 pupils, that of Tina and Nika by 25 pupils, to be rewarded by 100 golden coins per year and second one to get 50 golden coins. (Archives of museum of Shkodra, file of education). Also he stressed that "If two teachers Mici and Tina Gjergji (Tereza seemed to be in a negotiation to join the Italian school, our note E.B) will give up them and will be poor after a long rewarding done by Mici for the education of girls" (Archives of museum of Shkodra, file of education). In 1891 the school of Tereza Berdica had 90 pupils.

In letter written on 9.10.1907, Guerini asked the Foreign Ministry of Vienna "... on an extraordinary reward at 200 goldren coins for sister Tina of Nika. She worked as a teacher, because her sister could not bear the capacity of those pupils. In this letter, Guerini asked for that schools to be equipped with materials for cutting and sawing, lessons that had a huge occupation in programme of Tina's school" (Archives of museum of Shkodra, file of education)

The Catholic Cleric by taking advantage of the Austrian aid, vifiyied its educational activity. In 1875, the Jesuits open an elementary school. Two years later "Kolegja Severiane" was open. The Albania language was as a special language since its establishing. The programme aimed: "...by irrigating pupils (with teachers) to use the language and to provide them with necessary expressions for communication in writing and speaking in commerce" (1921). Since the first year the registers had a collumn for albanian language and on the note book of grades as well as per annual awards there were special prizes for Albanian language. During the first three years the subject of grammar was taught by At Luigj Mazza, in 1880 - 1884 by Dedë Pazi. The Jesuits published in their publishing house some religious books in albanian language.

The schools were chaired by Cleric and subsedized by the Austrians - Hungarins such as those schools of Shiroka (1874), Troshani (1882), Bajza in Kastrat (1883), Blinisht (1891), Selca of and Kelmend (1891). For the last one it was writen that: "...In year 1893 P. Joakin Serreqi O.F.M. renovated in Selca a school with sufficient area for 50 pupils. In this year P. Basil Chiaroni, O.F.M had opened an Albanian School in Hot (Traboin) and Pllana (1898)" (Prendushi, 
1974)

The founder of Shiroka School was Zef Ashta, who even under religious uniform worked to spread education and Albanian language. In this "small school" learned writing, reading and little arithmetic. But it was close to church and was a property of the farmers in the village. It had a classroom for teaching, a room for teachers and a kitchen. The first pupils were round 15-16 persons. (Troshani, 1963)

In one of old documents taken from registry of curacy of Shiroka, page 22, it says that: "The school or little school for boys, started in year 1874 open and kept by religious people that served at curacy. So the boys of Shiroka had a good chance to learn how to write, read, and little arithmetic".

At the end of year $1881-82$, ended the academic year and administration by curacy. In 1882, Perakly Bonatti arrived as a teacher, who was paid by the cash money from the village. On Sundays, the residents of this village (fishermen) fished all together and the revenues of that day were donated into cash box of village. Some of those revenues were used to buy books and other educational equipment for a good majority of children. Mister Perikli Bonatti worked as a teacher in Shiroka up to 1889. Still it is not known if he has worked or has been replaced by any other teachers till the arrival of a new teacher Ndoc Ronkali. In 1891, Ndoc Ronkali comes as a teacher in Shiroka who served here till year 1919. His arrival was welcomed by a ceremony, which was similar to a real fest in the village, where all residents of Shiroka attended. By his arrival all things changed in this school even the way how the lessons were conducted. His service, equipment and materials were paid by the Austrian Consul in Shkodra. During his service, he tried to stand not only for being closer to children but also to be closer to their parents. While working there, he did not only teach but also cultivated love for the country, love for independence, provided advices even for hygienic conditions and health problems. It was important the fact that in the school the religious lessons did not take place even the subject of religion was taught by the priest at the church. The working system was with two shifts in morning and afternoon. The Wednesdays and Sundays were day off-s. There was only one map but there were no other things. The pupils used ink. A special importance was stressed for physical training and songs (art). In arithmetic they learned about big numbers and problems. At the end of the academic year, after passing a kind of an exam, the delivering of acknowledgments was organized with a small ceremony. The final exams were done in front of religious authorities and Austrian - Hungarian Consul (Archives of museum of Shkodra, file of education)

The best pupils got gifts. In this school studied about 50 pupils. In letter of date 13 July 1909 Ndoc Ronkali took 115 coronas, an award by the Archbishop. Guerini asked to Vienna always for awards (Archives of museum of Shkodra, file of education)

In different documents we can see that each year the Archbishop of Shkodra asked continuously about the schools, an aid by the Austrian - Hungarian Consul in Shkodra or by the Foreign Ministry in Vienna. That money with regular quittances was distributed among teachers.

The Austrian - Hungarian support and publishing in different organs of press in Albanian language. So on 27 December 1904, established in Vienna by the cultural association "Knowledge", chaired by Gjergj Pekmezi, a Wiseman and patriot, who provided an important contribution for publication of books to Albanian schools.

\section{Conclusion}

The contribution of Austrian - Hungarian consulate in opening and running of schools has been huge. Due to this contribution they played an important role in education of young generation, brought the elementary steps of education and western model as well, but it affected that Shkodra very quickly to be changed into an educational and cultural centre. It is crucial that fact that those schools were not attended not only by boys but also by girls to fulfill the needs of that period, which had a practical goal and aimed to increase capability of pupils for the life.

Austria will continue to make contributions even later on, by offering education at its Universities who provided their contribution taken there, whom stood out in building of Albanian State.

\section{References}

Achives of Museum of Shkodra, File of Education, Nr.4562/2

Archives of Museum of Shkodra, Archive of Vienna

Bushati,H :"Materials for Shkodra", manuscript

Bushati, H (1973):"Situation of Education in Albania under the Ottomae period", manuschipt.

Denelli Gj.(2007): "Toward renessaince of traditional friendship", Shkodra

Fishta, Gj (1917) Dera e Absburgëve e lavrimi katolik n'Shqypnie, "Posta e Shqipnis", nr. 74, 
Group Authors, (1984): "History of Albania Peopler", volume II, "Economic \& Socail Development in ALbania", Tirana.

Kastrati, J.(1963) :"Contribution about history of education in district of Shkodra up to year 1912", "Arsimi Popullor", Nr. 2, Tiranë.

Kurti, D.(1935):"Cultural action of the catholic element in Albania", Shkodra.

Kurti,D(1993) : "Shkolla franceskane", "Kumbona e së diellës", Shkodër, 7 (13)

"Lirija"(1910) Selanik.

Luli, F.,Dizdari, I., Bushati, N.(1997):"In memories of generations", Shkodra.

"Progress",(1915), Shkodra, Nr.6, Nr. 10

Prenushi, M. (1974): "Hystorical observation on development of education in Shkodra century. XIX", Historical studies, Nr. 3.

"Programme of commercial schools in College of Sh.F. Saverit",(1921) Shkodra.

Qafëzezi, M.,I (1936): "Dhaskal Gjoka".

"Skopje", (1911), Nr. 12.

"Turksih schools in Shkodra",(1973) manscript, at Institute of Pedagocial Studies, Tirana, 1973 